\title{
Study of concordance in endothelial cell count after cataract surgery performed by novice or expert surgeons
}

\section{Estudio de la concordancia en el recuento endotelial tras cirugía de catarata realizada por cirujanos noveles o expertos}

\author{
Beatriz Alonso-Martín ${ }^{1 *}$, Juan C. Herranz-Heras ${ }^{1}$, Ignacio Cañas-Zamarra ${ }^{1}$, María Hernando-Portela ${ }^{1}$, \\ Elena Redondo-Martínez ${ }^{1}$, Rosa M. Sierra-Torres ${ }^{1}$, Agustín Gómez-de la Cámara ${ }^{2}$, and \\ Beatriz Sarmiento-Torres ${ }^{1}$ \\ ${ }^{1}$ Ophthalmology Department; ${ }^{2}$ Research Institute i+12. Hospital Universitario 12 de Octubre, Madrid, Spain
}

\begin{abstract}
Objective: To evaluate endothelial cell loss in patients after uncomplicated phacoemulsification comparing data from novice surgeons and expert surgeons. Method: An observational and prospective study was conducted in which 50 consecutive randomized eyes were evaluated in two groups of 25 eyes each. An endothelial cell count with specular microscopy was performed preoperatively and one month after surgery. Eyes with complicated cataracts were excluded. Results: Most of the patients were women, with a mean age of 75.5 years. The decrease in endothelial cell density one month after surgery was significant both in eyes operated by expert surgeons and novice surgeons, with a loss of $14.8 \%$ and $15.6 \%$, respectively, with no statistically significant difference $(p=0.491)$. Furthermore, the correlation between both groups was $0.58(p=0.0094)$. Cell loss in eyes operated by novice surgeons showed a good correlation (0.577) with the cumulative dissipated energy during phacoemulsification ( $p=0.0025)$, contrary to the results obtained with expert surgeons where this correlation could not be demonstrated. The total cumulative dissipated energy used by novice surgeons was significantly higher $(p=0.045)$; $63 \%$ more than expert surgeons. Conclusions: Phacoemulsification resulted in significant corneal endothelial cell damage with similar figures for both groups, showing a good correlation between them. Concerning endothelial cell loss, the safety of the procedure performed by novice surgeons is equivalent to that performed by experts.
\end{abstract}

Keywords: Endothelial cell. Microscopy. Phacoemulsification. Cataract. Safety. Surgeon.

\section{Resumen}

Objetivo: Evaluar la pérdida celular endotelial en pacientes operados mediante facoemulsificación de catarata no complicada, comparando datos de cirujanos noveles y cirujanos expertos. Método: Se realizó un estudio observacional y prospectivo en el que se evaluaron 50 ojos consecutivos aleatorizados en dos grupos de 25 ojos cada uno. Se realizó a cada ojo recuento de células endoteliales mediante microscopía especular preoperatoriamente y al mes de la cirugía. Los ojos con cataratas complicadas fueron excluidos. Resultados: La mayoría de los pacientes eran mujeres, con una edad media de 75.5 años. La disminución de la densidad celular al mes de la cirugía fue significativa tanto en ojos operados por cirujanos expertos como por cirujanos noveles, con una pérdida del $14.8 \%$ y el $15.6 \%$, respectivamente, sin diferencia estadísticamente

Correspondence:

*Beatriz Alonso Martín

Avda. de Córdoba s/n

Date of reception: 24-05-2020

Date of acceptance: 12-05-2021

E-mail: Beatriz alonso @live.com

DOI: 10.24875/RMOE.M21000180
Available online: 01-09-2021 Rev Mex Oftalmol (Eng). 2021;95(5):187-196

www.rmo.com.mx 2604-1731/@ 2021 Sociedad Mexicana de Oftalmología. Published by Permanyer. This is an open access article under the CC BY-NC-ND license (http://creativecommons.org/licenses/by-nc-nd/4.0/). 
significativa $(p=0.491)$. Además, la correlación entre la pérdida de ambos grupos fue de $0.58(p=0.0094)$. La pérdida celular en ojos operados por cirujanos noveles demostró una buena correlación (0.577) con la energía acumulada disipada del ultrasonido durante la facoemulsificación $(p=0.0025)$, frente a los expertos, en los que no pudo demostrarse esta asociación. El total de energía acumulada disipada empleada por cirujanos noveles fue significativamente mayor $(p=0.045)$, un 63\% más que los expertos. Conclusiones: La diferencia en el recuento endotelial tras cirugía de catarata se demuestra asociada a la propia cirugía, con cifras similares para cirujanos noveles y expertos, y se observa una buena correlación entre ambos grupos. Teniendo en cuenta la pérdida de celularidad endotelial corneal, la seguridad del procedimiento realizado por cirujanos noveles es equivalente a la del realizado por expertos.

Palabras clave: Células endoteliales. Microscopía. Facoemulsificación. Catarata. Seguridad. Cirujano.

\section{Introduction}

Senile cataract is a chronic disease associated with the aging process, and it is the main cause of reversible blindness in the world. It is estimated that $\mathbf{2 8 5}$ million people have some degree of visual impairment, of which $33 \%$ is due to cataracts ${ }^{1}$. Clinically, they are defined as decreased visual acuity caused by lens opacification and usually occur bilaterally.

At ages younger than 50-55 years, the prevalence is low, in the order of $0.2-7 \%$, but after $70-75$ years of age, cataracts affect $40-60 \%$ of the population or more, according to series ${ }^{2}$. The gradual rise in life expectancy has led to a substantial increase in the prevalence of cataracts, affecting a growing proportion of the population.

Phacoemulsification with intraocular lens implantation is the technique with the best overall relationship between costs and benefits in terms of restoring quality of life, and today it is the most widely used in our setting. This mechanized lens extraction technique was first described by Charles Kelman in 1967, based on the fragmentation and aspiration of cataract fragments using ultrasound, intervening inside the capsular bag through a small incision ${ }^{1}$.

One of the main complications of cataract surgery is the loss of endothelial cells derived from the surgical technique. The corneal endothelium is composed of a monolayer of mosaic-shaped hexagonal cells derived from the neural crest. It is the most important structure to preserve the transparency of the cornea and this depends on its preoperative status. The endothelium lacks proliferative capacity, but in the event of endothelial damage, either due to physiological causes secondary to age or traumatic causes such as eye surgery, the monolayer mosaic is reestablished by an increase in size and migration of neighboring cells throughout the months following the injury, increasing the coefficient of variation of cell area (polymegathism) and decreasing the percentage of hexagonal cells (pleomorphism).

In young corneas, the mean cell density is around 3,500 cells $/ \mathrm{mm}^{2}$, with a coefficient of variation that is close to 0.25 and $70-80 \%$ of hexagonal cells. The endothelial cell density required to maintain corneal transparency is not exactly known, although it is believed that between 400 and 700 cells $/ \mathrm{mm}^{2}$ could be the threshold ${ }^{3}$.

The first specular microscope was introduced by Maurice in the late 1960s, this being the most objective modality to clinically evaluate the corneal endothelium without altering its function or morphology, and avoiding the possibility of infection transmission ${ }^{4-6}$.

For the reasons stated, we planned to carry out this study, the primary objective of which was to evaluate endothelial cell loss in patients undergoing uncomplicated cataract surgery, comparing the data of novice surgeons with those of expert surgeons. Likewise, we compared the cumulative dissipated energy (CDE) of the ultrasound used during the intervention between groups, evaluating if there is a correlation with endothelial cell loss for each group.

\section{Methods}

\section{Study design}

This is an observational, prospective, and randomized study of patients undergoing phacoemulsification in a period of 4 months in the ophthalmology department of a tertiary care hospital.

Fifty eyes of patients between 61 and 92 years old were included, which were evaluated consecutively and divided into two homogeneous groups regarding estimated surgical difficulty, with 25 eyes operated by adjunct surgeons and 25 by third-year residents of this hospital, always tutored. The follow-up, both before and after surgery, was carried out by the same surgeon. 
Eyes with a preoperative endothelial cell count $<1100 \mathrm{cells} / \mathrm{mm}^{2}$ or with a determination reliability $<50 \%$ were excluded. Eyes with complicated cataract criteria, defined in Table 1, and those with intraoperative complications were also excluded from the study. The endothelial cell count is evaluated systematically prior to cataract surgery to know the state of the endothelium, which allows planning additional protection strategies if necessary. This same measurement was repeated one month after surgery to compare pre-and postoperative endothelial cell loss.

\section{Collected variables}

Figure 1 shows all the variables collected in one patient (repeating all measurements and data collections in the remaining 49).

Data were collected with a non-contact specular microscope (Specular Microscope Perseus ${ }^{\circledR}$, CSO, Srl, Firenze, Italy). Regarding its operation, immediately after each acquisition, a summary screen is displayed (Fig. 2) that shows, on the one hand, the original image of the total number of cells based on their polymegatism (assigns a color according to the area) and their pleomorphism (assigns a color based on the number of sides). On the other hand, there is a menu where the following parameters are statistically evaluated: total area, measured area, standard error of the mean (SEM), average cell surface with an error given by the standard deviation, coefficient of variation (CV), hexagonality index (Ex), corneal thickness, density, and reliability index. These last two parameters are the ones that have been taken as a reference to carry out this study. Cell density is expressed in cells per square millimeter. This is the main data analyzed in our study.

On the other hand, the reliability index indicates the percentage of reliability of the analysis; the measurement is considered valid when this parameter is $>50 \%$.

All patients were operated on with the same phacoemulsification platform (Centurion ${ }^{\circledR}$ Silver System, Alcon-Novartis Pharma, USA). All cataract interventions were carried out under intracameral anesthesia with $1 \%$ lidocaine and through a $2.2 \mathrm{~mm}$ incision. The corneal endothelium was protected with viscoelastic, Biolon ${ }^{\circledR}$ PRIME (Bio-Technology General [Israel], molecular weight 3,000,000 Dalton) and Healon ${ }^{\circledR 5}$ (Abbott Medical Optics, Inc., molecular weight $>3,000,000$ Dalton). An intraocular lens (CT ASPHINA ${ }^{\circledR}$ 409M/MP
Table 1. Complicated cataract criteria

\begin{tabular}{|c|c|}
\hline $\begin{array}{l}\text { Complicated cataract } \\
\text { (overall) }\end{array}$ & $\begin{array}{l}\text { Complicated cataract } \\
\text { (when teaching) }\end{array}$ \\
\hline Hypermature cataract & Single eye \\
\hline Synechiae & Very young patients \\
\hline Pseudoexfoliation & $\begin{array}{l}\text { Patients with complications in } \\
\text { the other eye in previous } \\
\text { surgeries }\end{array}$ \\
\hline $\begin{array}{l}\text { Low endothelial count or } \\
\text { guttas }\end{array}$ & Uncooperative patients \\
\hline Corneal leukoma & $\begin{array}{l}\text { Patients with significant } \\
\text { systemic pathology }\end{array}$ \\
\hline $\begin{array}{l}\text { Presence of other ocular } \\
\text { pathologies }\end{array}$ & Posterior polar cataract \\
\hline Very narrow anterior chamber & $\begin{array}{l}\text { Very nearsighted or farsighted } \\
\text { eyes }\end{array}$ \\
\hline \multicolumn{2}{|l|}{ Toric lens indication } \\
\hline \multicolumn{2}{|l|}{$\begin{array}{l}\text { Intraoperative floppy iris } \\
\text { syndrome }\end{array}$} \\
\hline \multicolumn{2}{|l|}{ Poor mydriasis } \\
\hline $\begin{array}{l}\text { Dislocations, subluxations, or } \\
\text { malformations }\end{array}$ & \\
\hline
\end{tabular}

\section{ZEISS or ABBOT TECNIS ${ }^{\circledR}$ PCB00 Monofocal 1-Piece} IOL) was implanted in the capsular bag. Anti-infective prophylaxis was performed with $5 \%$ povidone-iodine preoperatively and postoperatively in the conjunctiva, together with the administration of intracameral cefuroxime at the end of the surgery. Moxifloxacin and dexamethasone eye drops were prescribed as postoperative treatment. The surgical technique was defined by the surgeon according to the individual characteristics of each case. At 24 hours and a week after surgery, we evaluated the integrity of the incisions, the position of the lens, the absence of infectious and inflammatory signs, and the presence of corneal edema. One month after the intervention, refraction and endothelial count were evaluated.

The phacoemulsification machine displays a screen at the end of the intervention showing all the variables of the recently completed case (Fig. 3). From it, we collected the CDE of the ultrasound used during the intervention, to correlate it with endothelial cell loss. Other information that was also collected was total surgery time, total time U/S, total aspiration time, estimated fluid used, average torsional amplitude (PP3), time on total torsional amplitude, average equivalent torsional amplitude (PP3), 


\begin{tabular}{|c|c|}
\hline \multicolumn{2}{|l|}{ Presurgical cell count } \\
\hline Total Area $\left(\mathrm{mm}^{2}\right)$ & 0.15 \\
\hline Measured area $\left(\mathrm{mm}^{2}\right)$ & 0.5 \\
\hline Measured area (cell) & 138 \\
\hline SEM & 12.53 \\
\hline Reliability index & 54 \\
\hline Area $(\mathrm{Agv} \pm \mathrm{SD})\left(\mu \mathrm{m}^{2}\right)$ & $387 \pm 147.2$ \\
\hline Density (Cell/mm²) & 2584 \\
\hline $\mathrm{CV}$ & 38 \\
\hline EX (\%) & 46 \\
\hline Corneal thickness $(\mu \mathrm{m})$ & 515 \\
\hline Surgery & $11: 35: 00$ minutes \\
\hline \multicolumn{2}{|l|}{ Complete Case } \\
\hline $\mathrm{CDE}$ & 5.22 \\
\hline Total time U/S & $00: 43.9$ \\
\hline Total aspiration time & 3:07 \\
\hline Estimated Fluid used (cc) & 71 \\
\hline & \\
\hline \multicolumn{2}{|l|}{ Ultrasound } \\
\hline Average torsional amplitude (\%) & 29.5 \\
\hline Average torsional amplitude (PP3) (\%) & 29.2 \\
\hline Time On Total torsional amplitude & $00: 43.4$ \\
\hline Average equivalent torsional amplitude (PP3) (\%) & 11.7 \\
\hline Average longitudinal power (\%) & 18.5 \\
\hline Time On Total longitudinal power & $00: 00.5$ \\
\hline Average equivalent ultrasonic power (PP3) (\%) & 11.9 \\
\hline \multicolumn{2}{|l|}{ Post-surgical cell count } \\
\hline Total Area $\left(\mathrm{mm}^{2}\right)$ & 0.16 \\
\hline Measured area $\left(\mathrm{mm}^{2}\right)$ & 0.04 \\
\hline Measured area (cell) & 81 \\
\hline SEM & 22.99 \\
\hline Reliability index & 49 \\
\hline Area $(\mathrm{Agv} \pm \mathrm{SD})\left(\mu \mathrm{m}^{2}\right)$ & $545 \pm 206.9$ \\
\hline Density (Cell/ $/ \mathrm{mm}^{2}$ ) & 1842 \\
\hline CV & 38 \\
\hline EX (\%) & 44 \\
\hline Corneal thickness $(\mu \mathrm{m})$ & 426 \\
\hline
\end{tabular}

Figure 1. Variables collected from one patient (repeating all measurements and data collections in the remaining 49). Data were collected with a non-contact specular microscope (Specular Microscope Perseus ${ }^{\circledR}, \mathrm{CSO}, \mathrm{Srl}$, Firenze, Italy).

average longitudinal power (PP3), time on total longitudinal power and average equivalent ultrasonic power (PP3).
The study was authorized by the scientific management area and research project management unit of the hospital, and it followed the Declaration of Helsinki principles 


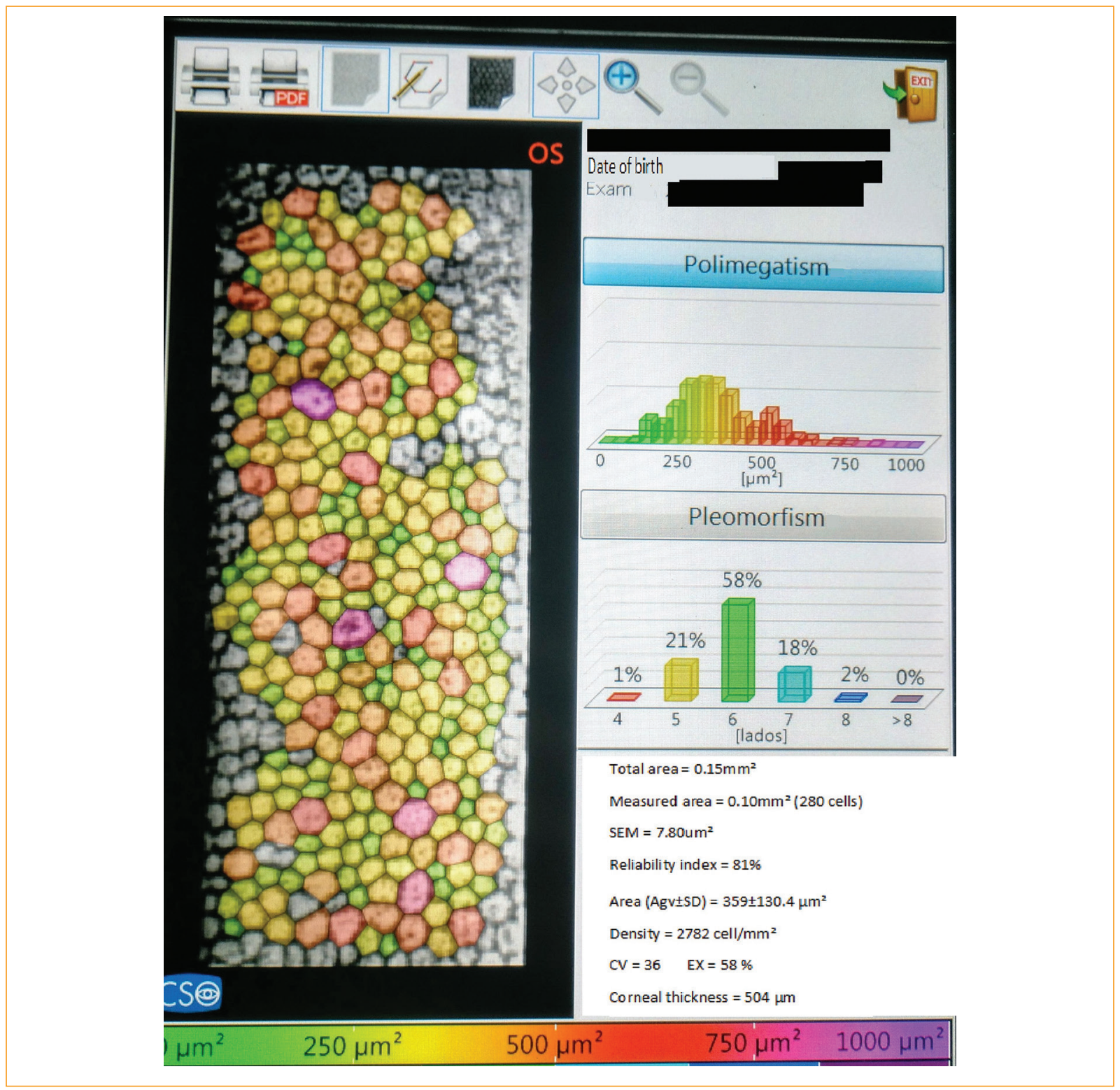

Figure 2. The summary screen of the device (Specular Microscope Perseus ${ }^{\circledR}, \mathrm{CSO}$, Srl Firenze, Italy). On the one hand, the original image is treated for the total number of cells based on their polymegatism (assigns a color according to the area) and their pleomorphism (assigns a color based on the number of sides). On the other hand, there is a menu where the following parameters are statistically evaluated: total area, measured area, standard error of the mean (SEM), average cell surface with an error given by the standard deviation, coefficient of variation (CV), hexagonality index (Ex), corneal thickness, density (2), and reliability index (1). These last two parameters are the ones that have been taken as a reference to carry out this study.

and the ethical standards of the hospital. Hospital security protocols have been respected to access medical record data and preserve the privacy of personal data.

\section{Statistical analysis}

A descriptive analysis was performed using the median $\left(50^{\text {th }}\right.$ percentile) and the interquartile range
( $25^{\text {th }}$ percentile $-50^{\text {th }}$ percentile) to describe the characteristics of the patients. The comparison between the main variables according to the surgeon's experience and the difference in density (pre-post) was performed with the non-parametric Mann-Whitney $U$ test and the median test.

The association between the difference in density and $\mathrm{CDE}$, and the difference in density between 


\begin{tabular}{|c|c|}
\hline \multicolumn{2}{|l|}{ Metric } \\
\hline \multicolumn{2}{|l|}{ Complete case } \\
\hline Case's Total Time & 18:01 \\
\hline Cumulative Dissipated Energy & 4.89 \\
\hline Total Time U/S & $00: 37.3$ \\
\hline Total Aspiration time & $3: 56$ \\
\hline Estimated Fluid Used & $53 \mathrm{co}$ \\
\hline \multicolumn{2}{|l|}{ Ultrasound } \\
\hline Average torsional amplitude & $32.1 \%$ \\
\hline Average torsional amplitude (PP3) & $31.7 \%$ \\
\hline Time On Total torsional amplitude & $00: 36.8$ \\
\hline Average equivalent torsional amplitude (PP3) & $12.7 \%$ \\
\hline Average longitudinal power & $31.4 \%$ \\
\hline Average longitudinal power (PP3) & $0.4 \%$ \\
\hline Time On Total longitudinal power & $00: 00.5$ \\
\hline Average equivalent ultrasonic power (PP3) & $13.1 \%$ \\
\hline
\end{tabular}

Figura 3. Summary screen of the surgical parameters collected from the device (Centurion ${ }^{\circledR}$ Silver System, Alcon-Novartis Pharma, US).

subpopulations of surgeons (expert and novice), were obtained using the Spearman correlation coefficient.

The statistical program used was SAS version 9.4. Values of $p<0.05$ were considered statistically significant for all analyses.

\section{Results}

\section{Sample characteristics}

The main characteristics of the patients are shown in Table 2.

Expert surgeons operated on the eyes of patients with a mean age of 72.9 years, $88 \%$ female and $56 \%$ right eyes. Regarding the group of eyes operated by novice surgeons, the mean age was 78.2 years, with $68 \%$ female patients and $76 \%$ right eyes.

\section{Comparison between novice and expert surgeons}

In the sample collected from eyes operated by expert surgeons, the median preoperative endothelial cell
Table 2. Characteristics of the patients included in the study

\begin{tabular}{|l|c|c|c|c|}
\hline & Female & Male & Right eye & Left eye \\
\hline $\begin{array}{l}\text { Novice } \\
\text { surgeons }\end{array}$ & $17(68 \%)$ & $8(32 \%)$ & $19(76 \%)$ & $6(24 \%)$ \\
$\begin{array}{l}\text { Expert } \\
\text { surgeons }\end{array}$ & $22(88 \%)$ & $3(12 \%)$ & $14(56 \%)$ & $11(44 \%)$ \\
\hline
\end{tabular}

density was 2569 cells $/ \mathrm{mm}^{2}$. After surgery, the endothelial count showed a decrease in cell density of $14.8 \%$, with a final count one month after surgery of 1965 cells $/ \mathrm{mm}^{2}$. The median CDE of ultrasound during phacoemulsification was 2.61 in this group.

Novice surgeons operated on eyes with a median preoperative endothelial cell density of 2462 cells $/ \mathrm{mm}^{2}$, losing $15.6 \%$ of cell density after surgery. The total CDE of ultrasound in this group was 4.12. Table 3 shows the main variables collected for the study.

Table 4 shows that there are differences between the median preoperative density, postoperative density, the difference in density, and CDE between expert and novice surgeons. However, only statistically significant differences were observed regarding the use of ultrasound (CDE) between both groups $(p=0.045)$.

\section{Comparison of density before and after surgery and its correlation with CDE}

In both groups, there was a statistically significant loss of endothelial cell density related to surgery, with $p=0.0008$ and $p=0.0035$ for expert surgeons and novice surgeons, respectively (Table 5).

In eyes operated by novice surgeons, a good correlation (0.577) was demonstrated between endothelial loss and CDE, with statistical significance $(p=0.0025)$. On the contrary, in eyes operated by expert surgeons, a poor correlation was obtained (0.306), without statistical significance $(p=0.135)$.

\section{Correlation of the difference in density between novice and expert surgeons}

Table 6 indicates that there is a statistically significant correlation of $0.589(p=0.0094)$ for the difference in density between novices and experts. 
Table 3. Variables collected by subgroups (expert and novice surgeons)

\begin{tabular}{|c|c|c|c|c|c|}
\hline Variable & Minimal & 50th percentile & Maximum & $\mathbf{N}$ & Missing \\
\hline $\begin{array}{l}\text { Expert surgeons } \\
\text { Preop density (cells/mm²) } \\
\text { Postop density (cells/mm²) } \\
\text { Difference in density } \\
\text { CDE }\end{array}$ & $\begin{array}{c}1822.00 \\
1248.00 \\
-150.00 \\
0.62\end{array}$ & $\begin{array}{c}2569.00 \\
1965.00 \\
382.00 \\
2.61\end{array}$ & $\begin{array}{c}2846.00 \\
2801.00 \\
1088.00 \\
6.93\end{array}$ & $\begin{array}{l}25 \\
25 \\
25 \\
25\end{array}$ & $\begin{array}{l}0 \\
0 \\
0 \\
0\end{array}$ \\
\hline $\begin{array}{l}\text { Novice surgeons } \\
\text { Preop density (cells/mm²) } \\
\text { Postop density (cells/mm²) } \\
\text { Difference in density } \\
\text { CDE }\end{array}$ & $\begin{array}{c}1126.00 \\
733.00 \\
19.00 \\
0.62\end{array}$ & $\begin{array}{c}2462.00 \\
1760.00 \\
386.00 \\
4.12\end{array}$ & $\begin{array}{c}2964.00 \\
2770.00 \\
1302.00 \\
20.13\end{array}$ & $\begin{array}{l}25 \\
25 \\
25 \\
25\end{array}$ & $\begin{array}{l}0 \\
0 \\
0 \\
0\end{array}$ \\
\hline
\end{tabular}

CDE: cumulative dissipated energy.

Table 4. Comparison between subgroups (experts and novices)

\begin{tabular}{|l|c|}
\hline Variable & p \\
\hline Preop density (cells/mm²) & 0.285889 \\
\hline Postop density (cells/mm²) & 0.142934 \\
\hline Difference in density & 0.490938 \\
\hline CDE & 0.045642 \\
\hline
\end{tabular}

CDE: cumulative dissipated energy.

Table 5. Comparison of the difference in density before and after surgery between groups

\begin{tabular}{|l|c}
\hline Variable & p \\
\hline Cells $/ \mathrm{mm}^{2}$ in expert surgeons & 0.0008 \\
\hline Cells $/ \mathrm{mm}^{2}$ in novice surgeons & 0.0035
\end{tabular}

Table 6. Correlation of the difference in density between novice and expert surgeons

\begin{tabular}{l|c} 
& $\begin{array}{l}\text { Difference in density } \\
\left.\text { (cells/mm }{ }^{2}\right) \text { in novice surgeons }\end{array}$ \\
\hline $\begin{array}{l}\text { Difference in density } \\
\left(\text { cells } / \mathrm{mm}^{2}\right) \text { in expert surgeons }\end{array}$ & $\begin{array}{c}0.58988 \\
(p=0.0094)\end{array}$
\end{tabular}

\section{Discussion}

The only definitive treatment for cataracts is surgery. Over time, phacoemulsification has replaced extracapsular lens extraction, and currently, it is the most widely used technique in the world ${ }^{7,8}$. Most of the advantages offered by phacoemulsification over extracapsular extraction are related to the small incisions $(1.5-3 \mathrm{~mm})^{9}$ that do not require suturing in most cases. This reduces surgically-induced astigmatism ${ }^{9,10}$ and allows a prompt visual rehabilitation for the patient's daily activities ${ }^{10}$. Furthermore, phacoemulsification induces less postoperative inflammation and a slighter breakdown of the blood-retinal barrier compared to extracapsular extraction ${ }^{11,12}$. Regarding the technique, it requires a slow and complex learning process, but there has not been an associated increase in the rate of complications ${ }^{13,14}$.

What differentiates phacoemulsification from other techniques is the fragmentation of the nucleus and subsequent aspiration of the fragments using ultrasound, and there are different ways to do this. In this study, all novice surgeons operated using the "divide and conquer" technique, which consists of breaking the nucleus into several fragments by carving grooves with the tip of the phaco machine (thereby releasing ultrasound energy $)^{15}$, to subsequently fracture the nucleus $^{16}$. As for the expert surgeons, some operated with this technique, while others did so with the "phaco chop" technique, that is, by initial fragmentation of the nucleus aided by a cutting instrument (chopper), thereby avoiding carving grooves and minimizing the use of ultrasound energy ${ }^{17}$. The number of expert surgeons who used each technique was not taken into account. Both "divide and conquer" and "phaco chop" are included within the endocapsular techniques that are characterized by working in a plane further away from the iris, with less cell loss than supracapsular techniques ${ }^{18}$. However, in our hospital, novices work in a more anterior plane for fear of damaging the posterior capsule, with a greater risk of affecting the endothelium.

From the results obtained, we infer that phacoemulsification is associated with a loss of endothelial cells, 
which would imply that the loss is a real consequence of surgery and not due to chance.

The percentage of loss varies greatly depending on the technique. According to some authors, the "divide and conquer" technique produces a statistically significant greater loss than the "phaco-chop" technique, as it is related to a longer ultrasound time and the use of higher ultrasound energy ${ }^{19}$. However, both techniques show comparable results and complications ${ }^{19}$. In this study, we observed a greater loss of endothelial cells in the eyes operated by novice surgeons, $15.6 \%$, compared to expert surgeons, $14.8 \%$, but this difference was not statistically significant. On the contrary, the correlation of cell loss between both groups was good, which means that the results in terms of endothelial loss between one and the other are superimposable, that is, in terms of maintaining a good endothelial reserve, there are minimal differences between being operated by a novice surgeon or by an expert one. The results obtained are in the range of those observed in other studies ${ }^{20}$, considering the scarcity of literature on the subject, since studying it from the teaching point of view is a novel topic, when comparing surgeons in training with experienced surgeons.

Regarding total CDE used by novice and expert surgeons, we found a significant difference in the use of ultrasound, which can be explained by a less refined technique used by novice surgeons. The reduced use of ultrasound energy by expert surgeons may be related to surgical time. In this study, a difference of 5 ' and 34 " was observed between both groups, with a mean time of $15^{\prime} 19^{\prime \prime}$ for novices, and of 9' $45^{\prime \prime}$ for experts. Reviewing other studies, Hosler et al. ${ }^{21}$ evaluated the evolution of mean surgical time in novice surgeons throughout the academic year, and concluded that at the end of the year the improvement was $42 \%$. In addition Randleman, et al. ${ }^{22}$ evaluated the progression in terms of surgical competence throughout the training of novice surgeons, and found that it progressively improves the efficiency of phacoemulsification and decreases the number of complications with increasing surgical experience, without reaching a plateau at any time. This could explain why novice surgeons are less efficient, as more experience is required to learn how to optimize the use of ultrasound through maneuvers such as occluded tip emulsification, pulsatile use of energy, take advantage of vacuum without ultrasound and less prolonged fluidics, which is put into practice by the expert surgeons of our hospital.

In relation to the above, the decrease in cell density observed in the group of novice surgeons was shown to be correlated with the use of ultrasound. Taking into account that they used $63 \%$ more ultrasound than the experts, the data obtained for this group is superimposable with the results of previous studies: the greater the use of ultrasound (CDE), the more endothelial cell loss $^{23}$. By contrast, for skilled surgeons, the loss did not correlate with $\mathrm{CDE}$, so it can be inferred that the decrease of endothelial cells in this group could be assumed as the expected minimum due to the hardness of cataracts ${ }^{24}$. It would be necessary to evaluate other intraoperative risk factors that may explain this loss.

Although the "divide and conquer" technique has become the standard method for teaching novice surgeons to safely and efficiently remove the nucleus in cataract surgery ${ }^{16,22}$, few studies have been conducted analyzing other techniques in novice surgeons. Gross, et al. ${ }^{25}$ comparatively studied the results obtained by novice surgeons in terms of CDE, ultrasound time, benefits and complications of the "divide and conquer" and "pop and chop" (a variant of "phaco-chop") techniques. As in this study, complicated cataracts and intraoperative complications were excluded. The "pop and chop" technique was confirmed to be safe and significantly more efficient than the "divide and conquer" technique, using less ultrasound energy and less surgical time in novice surgeons. Furthermore, the data suggest that the learning curve for this technique is short, allowing novice surgeons to achieve expertise earlier ${ }^{25}$. Unlike the "phaco-chop" technique, the "pop and chop" technique allows fragmentation of the nucleus under direct visualization by partially prolapsing it on the anterior lens capsule, in such a way that it is easier to learn and requires less surgical experience and expertise than "phaco-chop"26.

In uncomplicated surgeries, a loss of endothelial cells is also observed due to intraoperative mechanical damage caused by heat from the phaco machine tip, ultrasound, nuclear fragments, irrigation solutions, air bubbles, and the surgical instruments themselves ${ }^{27}$. These factors may have also influenced the endothelial damage observed with the techniques of novice surgeons and expert surgeons.

To protect the endothelium during intraocular interventions, in 1972 Balazs, et al. ${ }^{28}$ introduced the use of viscoelastic, which is classified into two types: cohesive and dispersive. Cohesive ophthalmic viscosurgical devices (OVDs) stands out for better maintaining and stabilizing spaces and tissues, as well as for being easy to inject and remove from the anterior chamber ${ }^{29}$. Howev$\mathrm{er}$, it tends to leak through the incision during phacoemulsification, leaving the corneal endothelium unprotected ${ }^{30}$. 
Dispersive viscoelastic does not conserve space as well as cohesive OVDs and is more difficult to remove, but it remains inside the anterior chamber during surgery, better covering and protecting endothelial cells ${ }^{30}$.

Overall, all OVDs protect the endothelium from particles and free radicals generated during the intervention. In addition, it allows better maintenance of the anterior chamber and endothelial protection, reducing the potential endothelial cell loss due to surgery ${ }^{31-33}$. Holzer, et al. ${ }^{34}$ compared five OVDs to assess the endothelial loss, including Healon $5^{\circledR}$. The results showed less loss in the eyes in which Healon $5^{\circledR}$ was used as a viscoelastic. This is a type of visco-adaptive viscoelastic (variable cohesion-dispersion index from 10 to 70) that behaves differently than the classic cohesive and dispersive ones, in such a way that it is capable of adapting from cohesive to pseudo-dispersive depending on the flow and the $\mathrm{cut}^{35}$, better protecting the endothelium and being easy to remove from the anterior chamber ${ }^{36}$. The novice surgeons used two types of OVDs: Biolon PRIME ${ }^{\circledR}$ (cohesive with medium density, cohesion-dispersion index of 37 ) and Healon $5^{\circledR}$, to compensate for their less experience with better protection of the corneal endothelium. However, expert surgeons used only Biolon ${ }^{\circledR}$. This reduced protection of the endothelium in the surgeries performed by expert surgeons could be a possible cause of the observed cell density loss. There would probably be an improvement if another OVDs was used that was more stable in the anterior chamber during phacoemulsification ${ }^{37}$.

Our study has several limitations since it includes a small number of cataract surgeries, which could produce a dispersion of the results, in addition to ignoring other factors that would contribute to the endothelial loss. It would be advisable to carry out studies in which the sample is enlarged and also take into account specific pathophysiological characteristics, such as the hardness of the lens and the depth of the anterior chamber. On the other hand, it would be interesting to divide the sample into two or more groups according to the technique used to fracture the lens ("divide and conquer," "phaco chop" or "pop and chop").

\section{Conclusions}

There is a greater loss of endothelial cells in eyes operated by novice surgeons than in those operated by expert surgeons, but the difference is not significant, in such a way that the endothelial loss is moderately superimposable if we consider the correlation between both groups. The lack of experience, which implies a greater use of ultrasound energy during phacoemulsification, is compensated by intraoperative protective measures, good tutoring, and prudence, reflected in a longer surgical time. This greater use of ultrasound would explain that there is a good correlation with endothelial loss in the group of novice surgeons, while in experts the correlation is low, so that endothelial cell loss would be attributable to factors other than ultrasound.

Through this study, we verified that the teaching provided in our department has two characteristics: it ensures a good technique in future generations of ophthalmologists and preserves patient safety. By reviewing our own methodology, we intend to help improve the surgical technique and teaching, which would ultimately translate into the satisfaction of the population we serve.

\section{Funding}

This research has not received specific aid from public agencies, commercial or non-profit entities. The article and research is part of the final master's degree in medicine, sponsored by the Universidad Complutense de Madrid.

\section{Conflicts of interest}

The authors declare no conflicts of interest.

\section{Ethical disclosures}

Protection of human and animal subjects. The authors declare that no experiments were performed on humans or animals for this study.

Confidentiality of data. The authors declare that they have followed the protocols of their work center on the publication of patient data.

Right to privacy and informed consent. The authors have obtained the written informed consent of the patients or subjects mentioned in the article. The corresponding author is in possession of this document.

\section{References}

1. Kelman CD. Phaco-emulsification and aspiration: a new technique of cataract removal: a preliminary report. Am J Ophthalmol. 2018;64:23-35.

2. Acosta R, Hoffmeister L, Roman R, Comas M, Castilla M, Castells X. Revisión sistemática de estudios poblacionales de prevalencia de catarata. Arch Soc Esp Oftalmol. 2006;81:509-16.

3. Martínez-Soroa I, Mendicute J. Endotelio y cirugía de catarata. En: Lorente R, Mendicute J, editores. Cirugía del cristalino. Madrid: Sociedad Española de Oftalmología; 2008. p. 276-7.

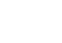


4. Ruggeri A, Scarpa F, De Luca M. A system for the automatic estimation of morphometric parameters of corneal endothelium in alizarine red-stained images. Br J Ophthalmol. 2010;94:643-7.

5. Doughty MJ, Müller A, Zaman ML. Assessment of the reliability of human corneal endothelial cell-density estimates using a noncontact specular microscope. Cornea. 2000;19:148-58.

6. Maurice DM. Cellular membrane activity in the corneal endothelium of the intact eye. Cell Mol Life Sci. 1968;24:1094-5.

7. Garcés Fernández A, Hernández López I, Carmona Pérez O, Peña López L, Santana Alas E, Arencibia González D, et al. Resultados anatómicos y funcionales en la cirugía de catarata mediante la técnica de extracción extracapsular del cristalino versus facoemulsificación. Rev Cubana Oftalmol. 2011;24:64-72.

8. Adenwala A. Historia de la facoemulsificación. Dominando la facodinámica. Herramientas, tecnologías e innovaciones. New Delhi: Jaypee Brothers; 2008. p. 3-10.

9. Watson A, Sunderraj P. Comparison of small-incision phacoemulsification with standard extracapsular cataract surgery: postoperative astigmatism and visual recovery. Eye. 1992;6:626.

10. Dam-Johansen M, Olsen T. Refractive results after phacoemulsification and ECCE: a comparative study. Acta Ophthalmol. 1993;71:382-7.

11. Oshika T, Yoshimura K, Miyata N. Postsurgical inflammation after phacoemulsification and extracapsular extraction with soft or conventional intraocular lens implantation. J Cataract Refract Surg. 1992;18:356-61.

12. Pande MV, Spalton DJ, Kerr-Muir MG, Marshall J. Postoperative inflammatory response to phacoemulsification and extracapsular cataract surgery: aqueous flare and cells. J Cataract Refract Surg. 1996;22:770-4.

13. Seward HC, Dalton R, Davis A. Phacoemulsification during the learning curve: risk/benefit analysis. Eye. 1993;7:164.

14. Apple DJ, Solomon KD, Tetz MR, Assia El, Holland EY, Legler UF, et al. Posterior capsule opacification. Surv Ophthalmol. 1992;37:73-116.

15. Mendicute J, Lorente R. Técnicas de fractura o cracking. En: Lorente R, Mendicute J, editores. Cirugía del cristalino. Madrid: Sociedad Española de Oftalmología; 2008. p. 662

16. Gimbel HV. Divide and conquer nucleofractis phacoemulsification: development and variations. J Cataract Refract Surg. 1991;17:281-91.

17. Lorente R, Mendicute J, De Rojas V. Faco-chop. En: Lorente R, Mendicute J, editores. Cirugía del cristalino. Madrid: Sociedad Española de Oftalmología; 2008. p. 683.

18. Mendicute J, Lorente R. Técnicas de fractura o cracking. En: Lorente R Mendicute J, editores. Cirugía del cristalino. Madrid: Sociedad Española de Oftalmología; 2008. p. 652-3.

19. Watson A, Sunderraj P. Comparison of small-incision phacoemulsification with standard extracapsular cataract surgery: postoperative astigmatism and visual recovery. Eye. 1992;6:626.

20. Chamorro F, Briones C, Loézar C, León A, Arancibia M, Stojanova J, et al. Pérdida celular endotelial corneal asociada a facoemulsificación y experiencia del oftalmólogo: análisis prospectivo de datos secundarios individuales. Medwave. 2018;18(6).
21. Hosler MR, Scott IU, Kunselman AR, Wolford KR, Oltra EZ, Murray WB. Impact of resident participation in cataract surgery on operative time and cost. Ophthalmology. 2012;119:95-8.

22. Randleman JB, Wolfe JD, Woodward M, Lynn MJ, Cherwek DH, Srivastava SK. The resident surgeon phacoemulsification learning curve. Arch Ophthalmol. 2007;125:1215-9.

23. O'Brien P, Fitzpatrick P, Kilmartin DJ, Beatty S. Risk factors for endothelial cell loss after phacoemulsification surgery by a junior resident. J Cataract Refract Surg. 2004;30:839-43.

24. Kreisler KR, Mortenson SW, Mamalis N. Endothelial cell loss following "modern" phacoemulsification by a senior resident. Ophthalmic Surg. 1992;23:158-60.

25. Gross FJ, Garcia-Zalisnak DE, Bovee CE, Strawn JD. A comparison of pop and chop to divide and conquer in resident cataract surgery. Clin Ophthalmol (Auckland, NZ). 2016;10:1847.

26. Chang DF. Learning phaco chop: pearls and pitfalls. New Orleans, LA: American Society of Cataract and Refractive Surgery; 2016.

27. Kohlhaas M, Klemm M, Kammann J, Richard G. Endothelial cell loss secondary to two different phacoemulsification techniques. Ophthalmic Surg. 1998;29:890-5

28. Balazs EA, Freeman MI, Klöti R, Meyer-Schwickerath G, Regnault F, Sweeney DB. Hyaluronic acid and replacement of vitreous and aqueous humor. Mod Probl Ophthalmol. 1972;10:3-21.

29. McDermott ML, Hazlett LD, Barrett RP, Lambert RJ. Viscoelastic adherence to corneal endothelium following phacoemulsification. J Cataract Refract Surg. 1998;24:678-83.

30. Koch DD, Liu JF, Glasser DB, Merin LM, Haft E. A comparison of corneal endothelial changes after use of Healon or Viscoat during phacoemulsification. Am J Ophthalmol. 1993;115:188-201.

31. Musch DC, Meyer RF, Sugar A, Soong HK. Endothelial rejection following penetrating keratoplasty using Healon or BSS. Cornea. 1990;9:305-11.

32. Alpar JJ. Use of Healon in different cataract surgery techniques: endothelial cell count study. Ophthalmic Surg. 1987;18:529-31.

33. Arshinoff S. Los viscoelásticos en la cirugía moderna de las cataratas. En: Lorente R, Mendicute J, editores. Cirugía del cristalino. Madrid: Sociedad Española de Oftalmología; 2008. p. 502-3.

34. Holzer MP, Tetz MR, Auffarth GU, Welt R, Völcker HE. Effect of Healon 5 and 4 other viscoelastic substances on intraocular pressure and endothelium after cataract surgery. J Cataract Refract Surg. 2001; 27:213-8.

35. Arshinoff SA, Jafari M. New classification of ophthalmic viscosurgical devices - 2005. J Cataract Refract Surg. 2005;31:2167-71.

36. Arshinoff SA, Wong E. Understanding, retaining, and removing dispersive and pseudodispersive ophthalmic viscosurgical devices. J Cataract Refract Surg. 2003;29:2318-23.

37. Martínez-Soroa I, Mendicute J. Endotelio y cirugía de catarata. En: Lorente R, Mendicute J, editores. Cirugía del cristalino. Madrid: Sociedad Española de Oftalmología; 2008. p. 281-3. 